IZA DP No. 8654

From Riches to Rags, and Back? Institutional Change, Financial Development and Economic Growth in Argentina since the 1890s

Nauro F. Campos

Menelaos G. Karanasos

Bin Tan

November 2014 


\title{
From Riches to Rags, and Back? Institutional Change, Financial Development and Economic Growth in Argentina since the 1890s
}

\author{
Nauro F. Campos \\ Brunel University, ETH Zurich and IZA \\ Menelaos G. Karanasos \\ Brunel University \\ Bin Tan \\ Southwest Jiaotong University
}

Discussion Paper No. 8654

November 2014

\author{
IZA \\ P.O. Box 7240 \\ 53072 Bonn \\ Germany \\ Phone: +49-228-3894-0 \\ Fax: +49-228-3894-180 \\ E-mail: iza@iza.org
}

Any opinions expressed here are those of the author(s) and not those of IZA. Research published in this series may include views on policy, but the institute itself takes no institutional policy positions. The IZA research network is committed to the IZA Guiding Principles of Research Integrity.

The Institute for the Study of Labor (IZA) in Bonn is a local and virtual international research center and a place of communication between science, politics and business. IZA is an independent nonprofit organization supported by Deutsche Post Foundation. The center is associated with the University of Bonn and offers a stimulating research environment through its international network, workshops and conferences, data service, project support, research visits and doctoral program. IZA engages in (i) original and internationally competitive research in all fields of labor economics, (ii) development of policy concepts, and (iii) dissemination of research results and concepts to the interested public.

IZA Discussion Papers often represent preliminary work and are circulated to encourage discussion. Citation of such a paper should account for its provisional character. A revised version may be available directly from the author. 
IZA Discussion Paper No. 8654

November 2014

\section{ABSTRACT \\ From Riches to Rags, and Back? Institutional Change, Financial Development and Economic Growth in Argentina since the 1890*}

Argentina is the only country in the world that was "developed" in 1900 and "developing" in 2000. The various competing explanations highlight, mainly, the roles of trade openness, political institutions, financial integration, financial development, and macroeconomic instability. Yet no study has, to the best of our knowledge, attempted a quantitative assessment of the relative importance of each of these competing explanations. This paper tries to fill this gap. It investigates their individual effects on economic growth and volatility using the power-ARCH framework with annual data since the 1890s. The results indicate that financial development and institutional change are the two main factors that help understand the extraordinary growth trajectory of Argentina over the last century.

JEL Classification: $\quad$ C14, O40, E23, D72

Keywords: economic growth, financial development, volatility, institutions, political instability, power-GARCH

Corresponding author:

Nauro F. Campos

Department of Economics

Brunel University

Uxbridge UB8 3PH

United Kingdom

E-mail: nauro.campos@brunel.ac.uk

\footnotetext{
* We would like to thank Nektarios Aslanidis, Thorsten Beck, Ralitza Dimova, Xavier Freixas, Peter Henry, John Hunter, Gregory James, Kyriacos Kyriacou, Marika Karanassou, Michael Koetter, Christopher Martin, Pierre-Guillaume Meon, Jeffrey Nugent, Antonio Savoia, Kunal Sen, Johan Swinnen, Keinichi Ueda, two anonymous referees and seminar participants at the CEPR Finance, Growth, and the Structure of the Economy Conference (Barcelona), EMG Conference at Cass Business School, University of Frankfurt, Federal Reserve Bank of Atlanta, Université Libre de Bruxelles and University of Manchester for valuable comments on previous versions. We also would like to thank Lee Alston and Andres Gallo for kindly sharing their data. The usual disclaimer applies.
} 


\section{Introduction}

The general economic trend since the Industrial Revolution has been one of economic betterment. Sustained increases in living standards are evident across most of the globe. In such a context, it would be startling to find any country that in 1900 was "developed" and in 2000 was "developing." Although placed among the ten highest incomes per capita in the world in 1900, "Argentina's ratio to OECD income fell to 84 percent in 1950, 65 percent in 1973, and a mere 43 percent in 1987 (...) Argentina is therefore unique" (della Paolera and Taylor, 2003, p. 5). This "Argentine puzzle" received a great deal of attention and scholars have identified several competing explanations, chiefly among them, financial development, political institutions, macroeconomic volatility, inflation, trade openness, and international financial integration. Surprisingly, however, there are no studies trying to quantify and assess the relative importance of this full array of potential reasons. This paper tries to fill this gap.

Within a power-ARCH (PARCH) framework and using annual time series data covering the period 1896 to 2000, the aim of this paper is to offer answers to the following questions. What is the relationship between, on the one hand, institutions, financial development, financial integration, inflation, and trade openness and, on the other, economic growth and volatility? Are the effects of these variables mostly direct (on economic growth) or indirect (via the conditional growth volatility)? Does the intensity (and sign) of these effects vary over are time? Does their intensity vary with respect to short- versus long-run considerations? Is the intensity of these effects constant across the different eras or phases of Argentine economic history (in other words, are they unaffected by structural breaks)?

This paper contributes to the vast literature on the causes of economic growth. Durlauf et al. (2005) and Acemoglu (2009) provide recent, authoritative surveys which suggest that there is widespread dissatisfaction with the empirical growth literature, while Sen (2013) and Spolaore and Wacziarg (2013) argue that within-country focus and historical quantitative research, respectively, may help to address such dissatisfaction. This paper contributes by focusing on one the most undisputed country outliers, as opposed to following more standard practice of focusing on the mean or median country. In this paper we (a) study only one individual country over a very long period of time, (b) use the economic history literature to guide the identification of potential reasons for the Argentine decline, (c) pay particular attention to two types of institutions (namely, political and financial institutions) that have figured prominently in the literature, and (d) choose an econometric methodology that has been seldom used in the empirical growth literature despite the fact that it allows to contrast the direct to the indirect (i.e., via the volatility channel) effects of each of the competing explanations, sort out their short- from their long-run impacts, and assess the impact of important structural breaks on the robustness of the main results. Another important benefit of this choice of econometric framework is that it helps to shed light on the relation between growth and volatility. While Ramey and Ramey (1995) show that growth rates are adversely affected by their volatility, Grier and Tullock (1989) argue that larger standard deviations of growth rates are associated with larger mean rates. Most ARCH papers focus solely on the growth-volatility relationship, or in other words, they seldom assess the effects of the presence of other variables. This paper examines if and how the growth-volatility relationship changes in light of a wider set of variables. 
We divide our econometric results in four different types of effects: direct (on mean economic growth), indirect (via volatility), dynamic (short and long-run) and structural break effects. Regarding the direct effects on economic growth, in the multivariate analysis we find evidence for a positive effect of the development of financial institutions (private and savings bank deposits to GDP). The results also show a negative growth effect from the instability of informal political institutions (guerilla warfare and general strikes). While financial and political institutions in our analysis emerge as first-order explanations, the results also suggest an important role for other two reasons (namely trade openness and international financial integration) and, to a much lesser extent, to inflation and public deficits. One explanation for such hierarchy is that our analysis tries to identify the explanations that have been important throughout the very long time window we consider. Consequently, one can argue that international financial integration and trade openness matter earlier (and/or that inflation may have been very important later on), but we do not find evidence that the importance of such factors have been consistent over the period 1890-2000.

As for the indirect effects on economic growth (through the growth volatility channel), our multivariate results show that the most robust of such indirect effects are from formal political instability (constitutional changes) and trade openness (negative in both cases). We find the large number of constitutional changes and the radical changes in trade policy have significantly contributed to dampen (the "expected" part of) growth volatility and this, by its turn, has a further negative effect on economic growth. There is also weak evidence for a positive effect of international financial integration (proxied by the UK interest rate) and of public deficits, but these set of results is not entirely robust in the sense that they weaken once we control for structural breaks.

In terms of the dynamic effects, the results show that changes in informal political institutions and international financial integration have affected Argentine growth negatively in the last hundred years or so both in the short-and the long-run. Interestingly, we find that the effects of political instability are larger in the short- than in the long-run, while those for financial development are negative in the short- but positive in the long-run. Notice that these latter effects do not always hold for the full set of proxies we use for financial development (they are particularly strong for savings deposits). We also find a negative short-run effect of trade openness, yet this effect is nullified in the long-run.

The fourth and last type of effect we estimate regards structural breaks. This is a crucial exercise given the very long-term nature of the data. We find that the main results just described are strengthened once structural breaks are taken into account. Some interesting checks are also provided, for instance, by learning that the direct effect of UK interest rates (international financial integration) on growth disappears with structural breaks.

In summary, our results indicate that financial and political institutions exhibit the most robust first-order effects on growth and volatility in Argentina since 1890. We argue for the preponderance of these two factors on the basis that their effects are significant either directly or indirectly and in both the short- and long-runs once we account for structural breaks. The growth effect of the development of financial institutions is positive and direct. It has a negative short-run effect and a positive larger long-run effect (this is particularly strong for the case of savings deposits.) According to these results, the debacle is explained instead by institutional collapse as informal political instability (in particular guerilla wars and strikes) 
shows a direct negative effect which is coupled with a negative short- and long-run impacts on growth, while formal political instability (constitutional changes) show equally significant and negative indirect effects on growth. Some additional results may be worth mentioning. International financial integration may also have contributed to the debacle because both short- and long-run effects are negative, but we could not find robust direct or indirect effects. Trade openness may have contributed as well because short-run and indirect effects are negative, yet we find no long-run effects on growth. The results for inflation and public deficits are also important but even less consistent.

These results suggest that institutional and financial factors have first-order effects in explaining the economic growth performance of Argentina since the 1890s. There has been considerable progress on our understanding of the economic effects of institutions for economic growth (Acemoglu et al, 2005) and development (Lin and Nugent, 1995). The results in this paper strongly suggest that the sustained institutional collapse (formal and informal political instability) can indeed be identified as a fundamental cause of long-run economic growth. Economic historians highlight the role of both political institutions and financial institutions in explaining economic growth over the long-run (Haber et al. 2008). The results in this paper support these views. Moreover, they show that these effects are strong enough to counter the positive impacts of financial development on economic growth (Levine 2005). One way of summarizing this interplay is to note that while the short- and long-run effects of institutions are found to go in the same direction (they are both negative for Argentina since the 1890s), only the long-run effect of financial development on growth is found to be positive (we find the short-run effect to be smaller and negative.) The two most important reasons for the economic decline of Argentina seem linked to financial and political institutions, with smaller and less clear roles played by international financial integration, trade openness, and inflation. Such smaller and less clear roles is captured by the relevant theoretical literatures (for financial integration see Bussiere and Fratzscher, 2008; for trade openness, see di Giovanni and Levchenko, 2009; and for public deficits see Dotsey and Sarte, 2000, Aghion and Marinescu, 2008, and Panizza and Presbitero, 2013.)

The paper is organized as follows. Section 2 briefly reviews the vast economic history literature on Argentina discussing various competing explanations that have been offered to the relative decline. Section 3 describes the data and Section 4 provides details on the econometric methodology. Section 5 presents the baseline econometric results. Section 6 concludes and suggests directions for future research.

\section{The Argentine Riddle}

There is little disagreement among economists that the period from 1875 to the eve of World War I is the Golden Age, or the Belle Époque, of Argentinean economic history (Taylor, 1992; Sanz-Villarroya,2007; Cortes Conde, 2009). Just to illustrate this, note that for the year 1913, della Paolera and Taylor (2003) estimate income per capita in Argentina to be (in 1992 US Dollars) around USD 3,797. They provide evidence that this figure is higher than the corresponding figures for France and Germany (USD3,452 and USD 3,134, respectively) and substantially larger than those for Spain or Italy. Massive inflows of foreign capital (physical as well as human) supported the rapid expansion of exports of primary products (grain, meat, 
wool and leather) which jointly with favorable international conditions, ultimately fuelled very rapid rates of economic growth (Rock, 1986, Cortes Conde, 2009). There is also little disagreement that the Argentina's uniqueness is because no other country climbed down from the selected group of advanced, rich or developed countries.

The major disagreement among economic historians to this day is not whether but actually when this unchecked decline started (and, of course, why it did). Some argue that it started with the 1930 crisis (e.g., Diaz-Alejandro 1985), others argue for an earlier turning point (for instance, Taylor suggests 1913), while Sanz-Villarroya (2005) estimates that the first important structural break for Argentina happens in $1899 .{ }^{1}$ Another way of depicting this process is given by Cortes Conde (2009): Argentina experienced a Belle Époque until WWI, a deceleration between WWI and WWII, and a decline starting after 1945.

Irrespective of exactly when the decline started, its existence was not undisputed until the immediate post II World War. In 1947 Argentina was still ranked 10th in the world in terms of per capita income (Alston and Gallo, 2010). della Paolera and Taylor (2003) note that "by 1900 Argentina's income per capita had risen from about 67 per cent of developed country-levels in 1870, to 90 percent in 1900, and 100 per cent in 1913 whatever its exact status in 1913, for all practical purposes Argentina was an advance country"(2003, p. 5). They also calculate that since then the ratio of Argentina's income to OECD income fell to 84 percent in 1950, then to 65 percent in 1973, and then to 43 percent in 1987.This ratio rebounds in the 1990s but again reverts with the 2001 crisisIt is also noteworthy that in a recent book on the Great Depressions of the $\mathrm{XX}^{\text {th }}$ century (Kehoe and Prescott, 2007), Argentina is the only country to which not one but two chapters are dedicated.

It is not surprising, therefore, that there is a vast literature on the Argentine puzzle, providing alternative explanations for its long-run relative economic decline (for surveys see della Paolera and Taylor, 2003, and Taylor, 2014). One argument is that increased direct competition in international markets during and after WWI (especially from the other areas of new settlement, i.e. Australia and Canada) has an important role to play, as does the sharp decline in immigration and foreign capital inflows.

Finance has also received a great deal of attention in terms of its potential role in explaining the Argentinean decline (della Paolera and Taylor, 1998). For example, Prados de la Escosura and Sanz-Villarroya (2009) argue that contract intensive money is a key factor in explaining the Argentinean puzzle. Taylor (2003) associates the Argentine decline to extremely low savings rates (the high population dependency rate linked to the immigration policy). This argument combines with Solberg's (1987) view and highlights the issue of (restricted) access to finance as a way of perpetuating high inequality levels. Moreover, the role of the financial sector does not need to be limited to domestic or national aspects. Many believe that there may have been excessive dependence on foreign capital in the Belle Époque (to British foreign capital) and the associated changes in global leadership (emergence of the US) after WWI as an important cause of the decline (Taylor, 1992).

Such radical shifts in market conditions extend from financial to goods markets, the

1 Below we present and discuss our Bai-Perron estimates of the date of structural breaks in Argentinean growth. We find (and adjust our estimates accordingly below) evidence for two structural breaks: 1922 and 1964 (for a fuller treatment of this issue, see Campos et al. 2011). 
emphasis for the latter being on international trade. Until 1914, Argentina was a successful exporter exhibiting very high levels of openness to international trade (measured as the ratio of exports plus imports to GDP.) Below we show that this ratio exceeds $50 \%$ in the years immediately before WWI, with a clearly declining trend in the inter-wars years (the ratio decreases from about $45 \%$ to $20 \%$ in these twenty years), and it never exceeds $25 \%$ from 1945 to about 2000. If one believes that exports alone are a major driving force of economic growth, then these numbers surely provide fuel to placing openness as a major reason for the Argentine decline (Diaz-Alejandro, 1985). One important caveat is that it is unclear (and still much debated) what were the reasons for such a reversal. In particular, the debate is whether this was mainly the disruption and closing up of international markets first with WWI and then with the Great Depression, or was it mainly the adoption of excessively protectionist policies by successive Argentinean governments. Note that these policies inspired and were later reinforced by the import substitution model advocated by a leading Latin American economist of the time, Raul Prebish (from Argentina.)

Figure 1: Ratio of Argentina's GDP per Capita to Developed Countries' GDP per Capita, 1885-2003

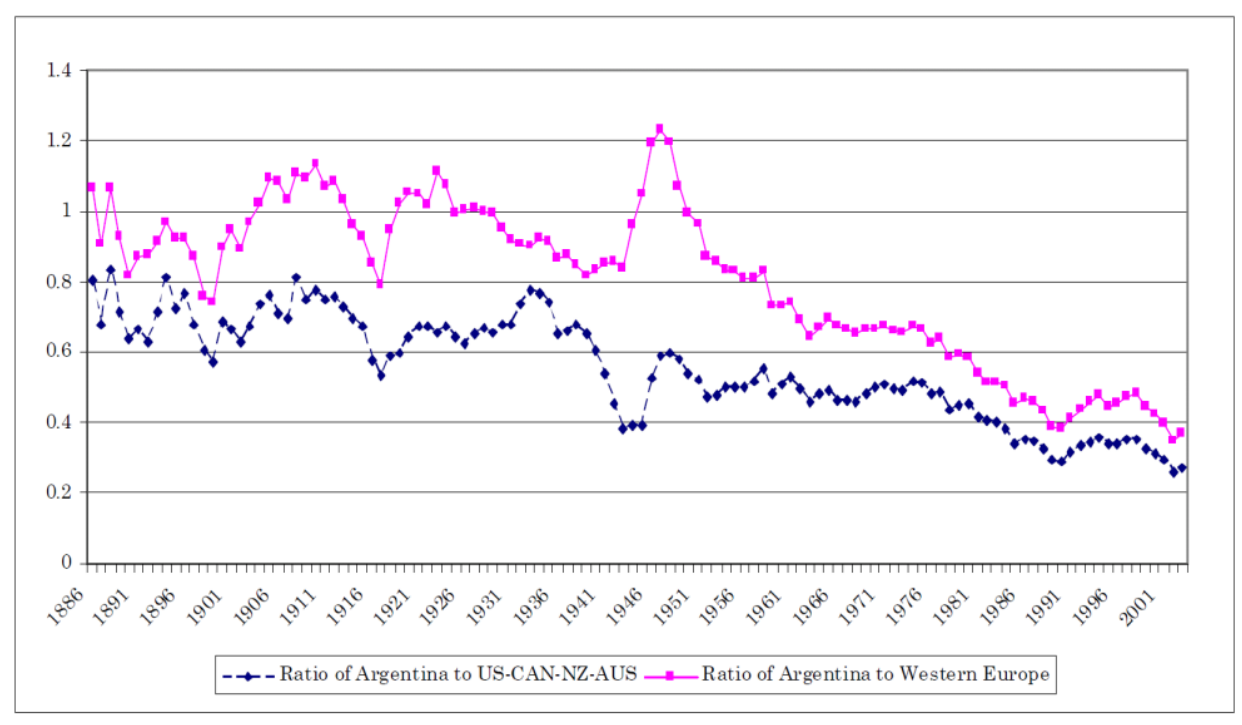

In addition to trade policies, many scholars believe that standard macroeconomic policies, in general, and their inconsistency and the resulting macroeconomic instability, in particular, are also to blame. For instance, della Paolera et al. (2003) show how public deficits throughout Argentinean history also seem to play an important role in explaining the decline. As mentioned above, we agree that these are important factors, yet here we try to identify factors that are consistently important throughout the period of analysis (below we find that these factors matter particularly in the years after 1973.)

Although there is a large literature associating the long-run relative decline of the Argentinean economy with political and institutional factors, ${ }^{2}$ we are unaware of studies that try to quantitatively evaluate this association. For instance, Acemoglu and Robinson (2006) observe that: "The political history of Argentina reveals an extraordinary pattern where democracy was created in 1912, undermined in 1930, re-created in 1946, undermined in 1955,

2 See also della Paolera and Taylor (2003) and references therein. 
fully re-created in 1973, undermined in 1976, and finally reestablished in 1983"(2006, p. 7). In a recent paper, Alston and Gallo (2010) identify the onset of widespread electoral fraud in the 1930s as a turning point for the erosion of the rule of law and one main reason for the Argentinean decline.

In what follows, we take all these considerations on board in trying to provide a comprehensive quantitative account of the relative importance of the main reasons often identified with the Argentinean debacle, namely political institutions (mostly in the form of political instability), domestic financial development, trade openness, macroeconomic volatility (inflation and public deficits) and integration in the international financial system.

\section{Data}

The data set we put together for this paper reflects the main factors identified by economic historians discussed above. The factors often associated with the relative economic decline of Argentina are the following: financial development, political instability (or institutions), macroeconomic volatility, inflation, trade openness, public deficit, and international financial integration.

Our basic data source is the Cross National Time Series Data set (Banks 2005) which contains historical series on income per capita and various dimensions of instability. ${ }^{3}$ This is a commercial database that has been extensively used in the scholarship on growth and political instability (Durlauf et al., 2005.)Data are available yearly for Argentina from 1896 until 2000, for various instability series, excluding the two World War years (that is, 1914 to 1918 and 1939 to 1945$)$.

Our two main measures of financial development try to capture the efficiency of the financial sector, not its relative size. The source for both is Mitchell (2003). The first is the bank deposits by the private sector over GDP (private deposits/GDP), which we believe is a good proxy for the share of credit to the private sector over GDP. Although the latter is a measure widely used in the literature, one must note that it is not available for Argentina for more than half of our sample (that is, it is available consistently only after 1960.) Our second measure from Mitchell (2003) is the total deposits in savings banks overdo. Given its more restrictive nature and the fact that the exact definition of savings bank deposits contains an unobservable legal element, we use this variable mostly for robustness check thereby attaching greater weight to private deposits. ${ }^{4}$

3 We have obtained GDP growth and level figures from various other sources (as well as industrial output series) and initial results (not reported) show that these different measures do not affect our results below.

4 For the sake of robustness, we re-estimate our models using two additional measures of financial development, both reflecting depth. The first is the ratio of M3 to GDP, from Alston and Gallo (2010). The main reason for considering this measure is that it has been used extensively in the finance-growth literature (see Levine 2005). The second is a narrower version of this variable (M1 over GDP) and the source of these data is Bordo et al. (2001). An Appendix (available upon request) contains figures and the relevant results (Table A1). 
Figure 2: Measures of Financial Development

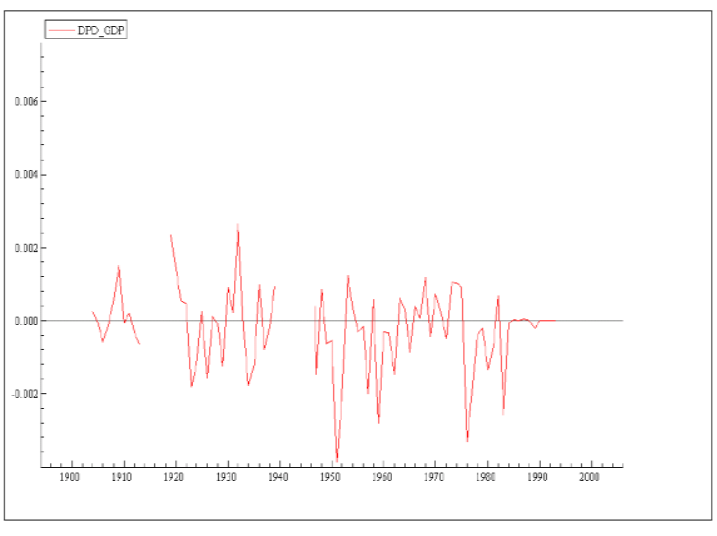

Private deposits over GDP

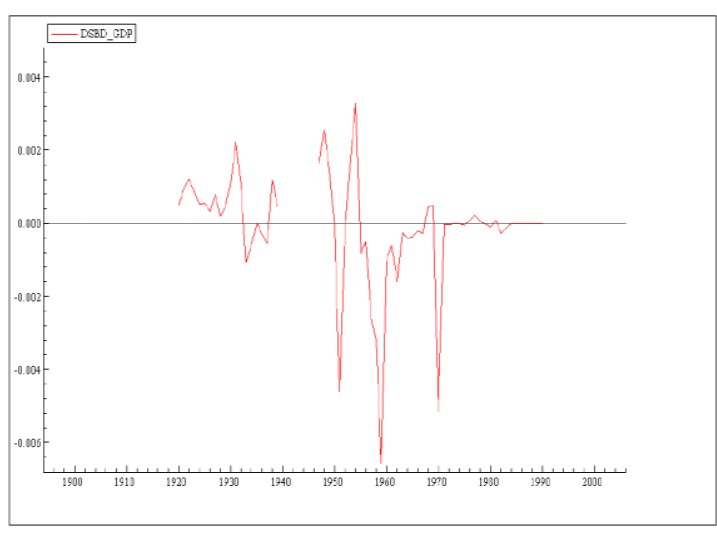

Savings banks deposits over GDP

We also explore the hypothesis that different types of political instability have different effects on economic growth. ${ }^{5}$ This is done by further developing the distinction between formal and informal political instability introduced in Campos and Karanasos (2008). The distinction is based on whether or not different forms of instability originate from within the political system: guerrilla warfare are thus informal political instability, while constitutional reforms are classified as formal instability. In addition to the obvious policy implications this taxonomy generates (in a literature in which policy implications are scarce), this distinction allows us to investigate questions that naturally have not been investigated sofa, such as whether or not the effects of some forms of informal instability are more severe in the short-than in the long-run, and whether or not the main effect of formal instability occurs through growth volatility. One of our hypotheses is that the answer to these questions is the same ("yes") and below we provide further justification as well as full econometric support.

Our informal political instability variables ${ }^{6}$ are strikes (this is a count variable reflecting general strikes of 1,000 or more workers involving more multiple employers and aimed at government policies) and guerrilla warfare (which is coded as a dummy variable for the occurrence in a given year of armed activity, sabotage, or bombings by independent bands of citizens and aimed at regime overthrow). The source for these is Banks (2005) which is perhaps one of the most widely used data sources in the relevant political science literature. These series are available since 1919 (Figure 3).

5 Another puzzle we are interested in regards the duration of the political instability effects: while the conventional wisdom is that these are severe in the long-run, Campos and Nugent (2002) and Murdoch and Sandler (2004) argue that they are significantly stronger in the shorter- than in the long-run. In Campos and Nugent (2002), the long-run effect vanishes when the African countries are excluded from the estimation and when institutions are taken into account.

6 Our political instability variables enter one by one in the econometric framework we use, so our results are not affected by the taxonomy and as such it is used simply to facilitate the interpretation. 
Figure 3: Measures of Informal Political Instability

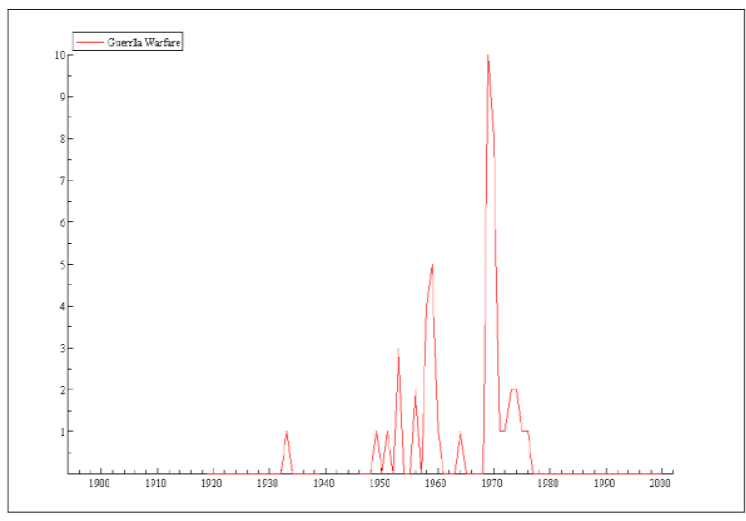

Guerilla Warfare

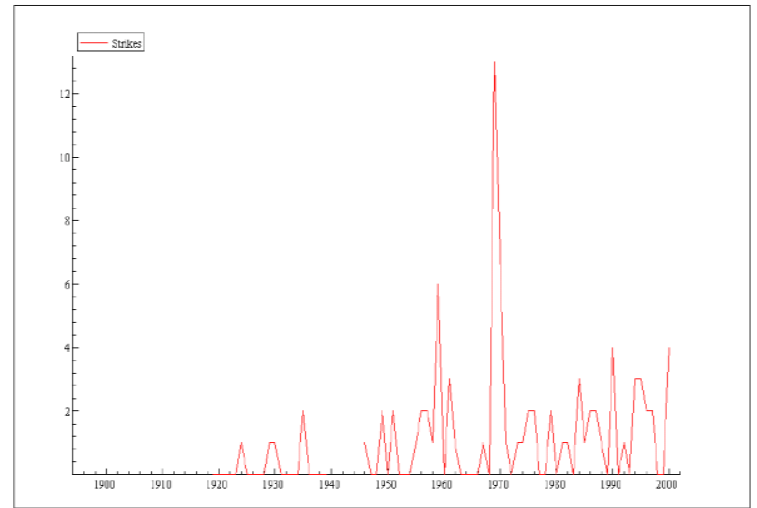

Strikes

Our formal political instability variable is shown in Figure 4 and is as follows: the number of constitutional changes. This is coded as a dummy variable reflecting the occurrence of the respective events. The data source is Banks (2005). ${ }^{7}$

Our measures of inflation, trade openness and public deficit are from Alston and Gallo (2010). Inflation is measured as yearly changes in the consumer price index (CPI). Public deficit is proxied as the ratio of the federal deficit to GDP, but it does exclude state-owned enterprises. $^{8}$ Trade openness is measured in standard fashion as the ratio of imports plus exports to GDP. Alston and Gallo (2010) have carried out various necessary adjustments to underlying data from Véganzonès and Winograd (1997), from the Ministry of Economy of Argentina and from the IMF's International Financial Statistics.

7 For the robustness purposes, results were obtained for two additional measures of informal political instability: the annual number of anti-government demonstrations (peaceful public gatherings of at least 100 people) and the number of assassinations (defined as politically motivated murders or attempted murders of a high government official or politician), as well as for three additional measures of formal political instability: the occurrence of legislative elections, the number of cabinet changes and the size of the cabinet. See the additional Appendix (which is available upon request) for further details.

8 Because the original inflation series contain a number of obvious outliers between the years 1987 and 1991 (reaching almost 5,000\% in 1989), we lower the relative weight of these observations for estimation. 
Figure 4: Measures of Formal Political Instability

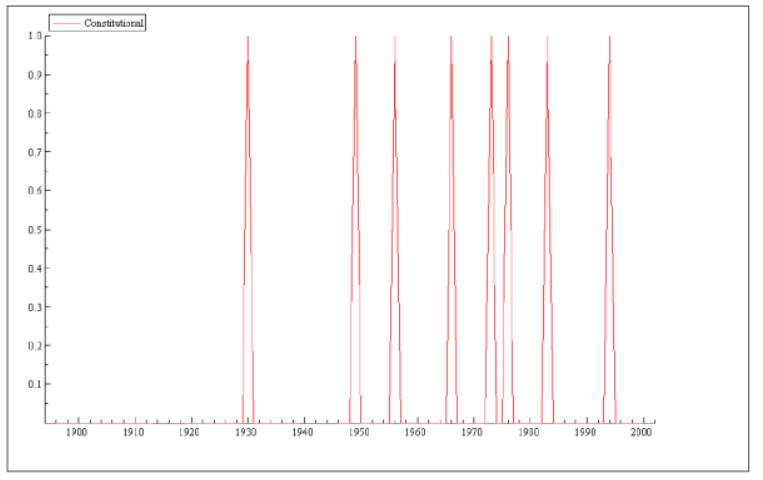

Constitutional changes

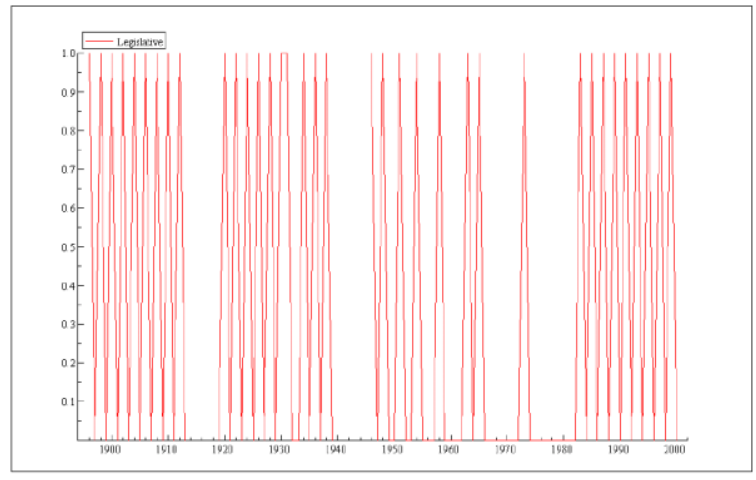

Legislative elections

Finally, international financial sector developments have also been repeatedly blamed for Argentina 'spoor economic performance. There are two aspects of this issue that are often said to play a role: the first being the credit crunch associated with the onset of WWI and with the Great Crisis of 1929, and the second being the change in global financial leadership which went from London to New York during this period. We must say that we proceed as if the second aspect is less important, but also that were absolutely sure it is much more difficult to measure than the first. Thus, in standard fashion in this type of study, we use the level of interest rates in the United Kingdom as our proxy for the overall conditions in international financial markets (the source of these data is Bordo et al. 2001). Because the transition to the U.S. financial leadership is often said to be even less beneficial to Argentina (mainly because American investors often refrained to take managerial control of Argentine firms), our estimates for this effect should be conservative and if at all biased will show a smaller than actual effect of the international financial market in the Argentinean decline.

Figure 5: Other Variables

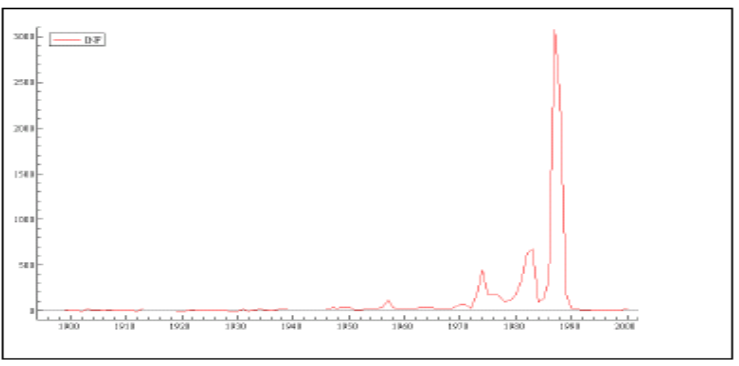

Inflation

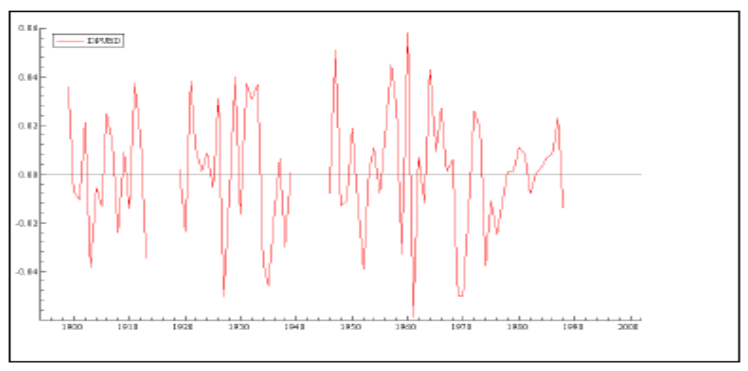

Public Deficit

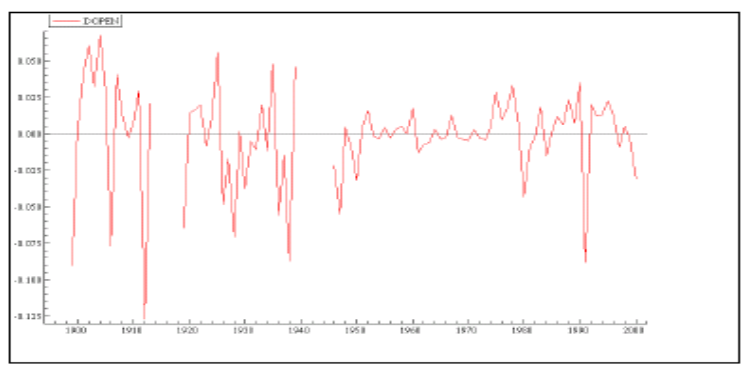

Trade Openess

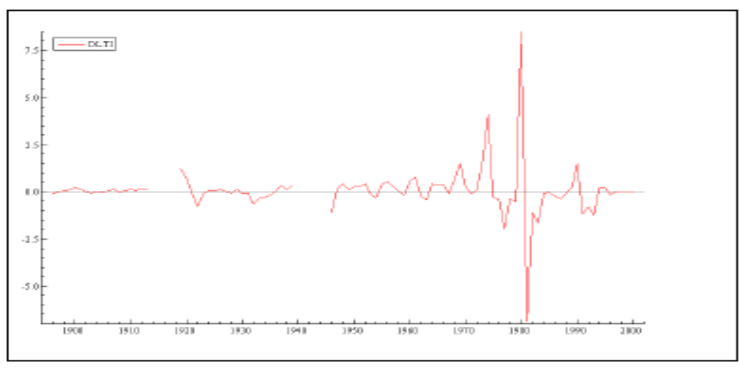

UK Interest Rate 


\section{Econometric Framework}

The PARCH model was introduced by Ding et al., (1993) and quickly gained currency in the finance literature. ${ }^{9}$ Let growth $\left(y_{t}\right)$ follow a white noise process augmented by a risk premium defined in terms of volatility:

$y_{t}=c+k h_{t}+\lambda x_{i t}+\varepsilon_{t}$

with $\quad \varepsilon_{t}=e_{t} h_{t}^{\frac{1}{2}}$

where $x_{i t}$ is either the political instability or the financial development variable or one of the other explanatory variables. ${ }^{10}$

In addition, $\left\{e_{t}\right\}$ are independently and identically distributed (i.i.d) random variables with $E\left(e_{t}\right)=E\left(e_{t}{ }^{2}-1\right)=0$; while $h_{t}$ is positive with probability one and is a measurable function of the sigma-algebra $\Sigma_{t-1}$, which is generated by $\left\{y_{t-1}, y_{t-2} \ldots.\right\}$ In other words, $h_{t}$ denotes the conditional variance of growth. In particular, $h_{t}$ is specified as an asymmetric $\operatorname{PARCH}(1,1)$ process with lagged growth included in the variance equation:

$h_{t}^{\frac{\delta}{2}}=\omega+\alpha h_{t-1}^{\frac{\delta}{2}} f\left(\mathrm{e}_{\mathrm{t}-1}\right)+\beta h_{t-1}^{\frac{\delta}{2}}+\phi x_{i t}+\gamma y_{t-1}$

with $f\left(e_{t-1}\right)=\left[\left|e_{t-1}\right|-\varsigma e_{t-1}\right]^{\delta}$

where $\delta$ (with $\delta>0)$ is the heteroscedasticity parameter, $\alpha$ and $\beta$ are the ARCH and GARCH coefficients respectively, $\varsigma$ with $|\varsigma|<1$ is the leverage term and $\gamma$ is the level term for the $l$ th lag of growth. In order to distinguish the general PARCH model from a version in which is fixed (but not necessarily equal to two) we refer to the latter as (P)ARCH.

We proceed with the estimation of the PARCH $(1,1)$ model in equations (1) and (2) in order to take into account the serial correlation observed in the levels and power transformations of our time series data. The Tables below report the estimated parameters of interest for the period 1896-2000.These were obtained by quasi-maximum likelihood estimation (QMLE) as implemented in EVIEWS. The best fitting specification is chosen according to the Likelihood Ratio (LR) results and the minimum value of the Information Criteria (IC) (not reported). Once heteroscedasticity has been accounted for, our specifications appear to capture the serial correlation in the power transformed growth series. ${ }^{11}$

Our set of variables tries to reflect the different explanations for the Argentinean puzzle previously put forward by economic historians. This set comprises domestic and international financial developments, informal and formal political instability, inflation and public deficit, and the degree of openness to international trade. In order to study the direct effects of our set of explanatory variables, we specify model 1 with $\emptyset=\gamma=0$ in equation (2), while model 2 with $\lambda=0$ in equation (1) allows us to investigate their indirect impacts on growth.

9 See Karanasos and Kim (2006) and references therein.

10 Because the original financial development, openness, public deficit and UK interest rate variables, are I(1), they enter in first differences.

11 For all cases, we find that the leverage term is insignificant, so we re-estimate our models excluding this parameter. 


\section{Econometric Results}

The discussion of the econometric results below is structured according to different types of effects: (1) direct effects (on mean economic growth), (2) indirect effects (via volatility), (3) dynamic effects (short and long-run) and (4) structural break effects.

\subsection{Direct Growth Effects}

Table 1 presents the full multivariate results, with informal political instability, domestic and international financial development, and trade openness. ${ }^{12}$ Both guerilla warfare and strikes show the expected negative and statistically significant direct impact (cf. the $\lambda_{1}$ column). As for the effect of financial efficiency, it is positive and statistically significant ( $\lambda_{2}$ column). It is worth noting that the influences of the UK interest rate and the trade openness on growth change qualitatively with the presence of informal political instability and financial efficiency. More specifically, the negative impact of interest rate on growth remains when we include in the model the impact of savings bank deposits on growth but it disappears when we include private deposits. Similarly, trade openness affects growth negatively only in two out of the four cases (see the $\lambda_{3}$ and $\lambda_{4}$ columns in Table 1). ${ }^{13} \mathrm{We}$ find a positive contemporaneous effect (in the univariate analysis) of inflation on the volatility of growth which is in line with the theory by Dotsey and Sarte (2000), yet in the multivariate analysis discussed below there is a significant lagged effect (results are available upon request).

As for the in-mean parameter $(k)$, notice that in all cases the estimates are statistically significant and positive which is in line with the theoretical argument of Black (see Fountas and Karanasos, 2007 and references therein). Also the power term coefficients $\delta$ are rather stable, with the Akaike information criteria (AIC) choosing a (P)ARCH specification with power term ranging from 0.8 (private deposits) to 1.10 (savings bank deposits.) ${ }^{14}$ We have also regressed the volatility of economic growth on the measures of financial development and find no significant effects. We estimate the direct and short-run effects with lagged inflation and public deficits as regressors and we find a significant negative influence from both variables.

In summary, we find that the main explanatory factors, solely in terms of their direct effects on economic growth in Argentina, turn out to be domestic (financial efficiency) financial development and informal political instability (guerrilla warfare and strikes.) Less robust are the negative direct effects of international financial integration and trade openness. We now turn to the investigation of the indirect effects.

12 The results for the one by one variable are presented in the supplementary Appendix which is available online.

13 Interestingly, this is not the case for the trivariate analysis. That is, when either UK interest rate or trade openness are included (but not both) there is the expected negative and significant influence in all cases (see Table A6 in an additional Appendix which is available upon request).

14 Notice that in all our estimations the ARCH and GARCH parameters ( $\alpha$ and $\beta$ ) are highly significant in the majority of the cases (see Tables 1 and 2). 
Table 1: Direct Effect of Guerilla Warfare/Strikes, Private Deposits/Savings Bank Deposits, UK Interest Rate, and Trade Openness on Economic Growth. (P)ARCH estimates

\begin{tabular}{lcccccccc}
\hline \hline & $k$ & $\lambda_{1}$ & \multicolumn{1}{c}{$\lambda_{2}$} & $\lambda_{3}$ & $\lambda_{4}$ & $\alpha$ & $\beta$ & $\delta$ \\
\hline & & \multicolumn{7}{c}{ Guerilla Warfare } \\
Private & 0.81 & -0.001 & 0.328 & -0.001 & -0.011 & 0.81 & 0.51 & 1.00 \\
Deposits/GDP & $(2.06)$ & $(3.32)$ & $(1.98)$ & $(1.40)$ & $(1.18)$ & $(4.42)$ & $(4.31)$ & - \\
Savings Bank & 0.75 & -0.001 & 0.147 & -0.004 & -0.014 & 0.96 & 0.52 & 1.10 \\
Deposits/GDP & $(1.54)$ & $(2.63)$ & $(2.16)$ & $(7.18)$ & $(2.50)$ & $(5.07)$ & $(7.46)$ & - \\
\hline & & & & Strikes & & & & 0.80 \\
Private & 0.74 & -0.002 & 0.263 & -0.001 & -0.046 & 0.89 & 0.43 & - \\
Deposits/GDP & $(2.15)$ & $(2.14)$ & $(1.69)$ & $(1.50)$ & $(6.89)$ & $(4.60)$ & $(2.86)$ & 1.10 \\
Savings Bank & 0.73 & -0.001 & 0.308 & -0.004 & -0.127 & 1.00 & 0.51 & - \\
Deposits/GDP & $(1.62)$ & $(2.01)$ & $(1.79)$ & $(5.17)$ & $(1.46)$ & $(3.87)$ & $(5.05)$ & - \\
\hline
\end{tabular}

Note: This table reports parameter estimates for the following model:

$y_{t}=c+k h_{t}+\lambda_{1} x_{i, t}^{(p i)}+\lambda_{2} x_{i, t}^{(f d)}+\lambda_{3} x_{u k, t}+\lambda_{4} x_{t o, t}+\varepsilon_{t}, \quad h_{t}^{\frac{\delta}{2}}=\omega+\alpha h_{t-1}^{\frac{\delta}{2}}\left|\varepsilon_{t-1}\right|^{\delta}+\beta h_{t-1}^{\frac{\delta}{2}}$

where $x_{i, t}^{(p i)}$ is either guerilla warfare or strikes, $x_{i, t}^{(f d)}$ is either private deposits/GDP

or savings bank deposits/GDP, $x_{u k, t}$ is UK interest rate, and $x_{t o, t}$ is trade openness.

The numbers in parentheses are absolute t statistics.

\subsection{Indirect Effects (Via Growth Volatility)}

One of the main advantages of the (P)ARCH framework is that it allow us to study not only the direct growth effects from the full set of explanatory variables described above, but also their indirect effects on economic growth through the predicted component of growth volatility (conditional on its past values). As we can see from Table 1 above and from Table 2 in this Section, the effect of conditional or predicted volatility on growth is in all (but two) cases positive $(k>0)$ and statistically significant at conventional levels. In this sub-section, we present our results for such indirect effects for the complete set (that is, including all the main explanatory variables).

Table 2 shows that adding to the baseline model the complete set of explanatory variables, the indirect negative effect of formal political instability is statistically significant. ${ }^{15}$ Focusing attention first on the $\emptyset_{1}$ and $k$ parameters, note that formal instability

15 The results for the one by one variable are reported in the supplementary Appendix. For the sake of space, the results for the intermediate steps (those in between the results for one by one variable and for all variables together) are reported in an additional Appendix which is available upon request. When we include in the variance of growth the UK interest rate and/or trade openness, and one of the four alternative measures of formal political instability, the effects of cabinet size and cabinet changes (in all but one cases) disappear (see in the additional Appendix Tables A8-A9 and A12). Therefore, in what follows we only use constitutional changes. Moreover when we control for formal political instability inflation has no impact on growth volatility (see tables A11 and A13). In addition, our 
(in this case, the occurrence of changes in the constitution) is found to affect conditional volatility negatively $\left(\varnothing_{1}<0\right)$. Economic agents have severe difficulties in anticipating the consequences of changes in the rules of the game (constitutions). Such changes increase the share of unanticipated uncertainty and this accordingly reduces growth. Since $k>0$, constitutional changes affect growth negatively as well. Of course, these results reinforce the notion that the type of political instability matters vis-à-vis economic growth: while informal (guerilla warfare and strike) may have direct effect, the impact of formal instability (constitutional changes) operates indirectly, via growth volatility.

There a number of other noteworthy results from Table 2. In particular, the impacts of UK interstate and public deficit on volatility are positive $\left(\varnothing_{2}, \varnothing_{4}>0\right)$ and statistically significant. On the other hand, we find evidence that increases in trade openness are associated with decreases in conditional volatility $\left(\varnothing_{3}<0\right)$ of per capita growth in Argentina.

The fact that exogenous increases in trade openness have a negative and significant impact on growth (recall that the direct effect is also negative) reflects one of the costs many economic historians associate with volatility: in the short-run, changes in the share of trade in GDP decrease the conditional or expected share of growth volatility (or, equivalently, increase the amount of growth volatility that economic agents are not able to anticipate.) Therefore such a decrease in conditional volatility driven by trade openness translate into lower rates of economic growth (because $k>0$ ). Although many scholars have given this explanation a great deal of weight and importance, the overall context of our results recommends a more limited role as the direct effects of trade openness are not as robust as those for financial and political institutions.

Table 2: Indirect Effect of Constitutional Changes, UK Interest Rate, Trade Openness, and Public Deficit on Economic Growth. (P)ARCH estimates

\begin{tabular}{cccccccccc}
\hline & $k$ & $\alpha$ & $\beta$ & $\phi_{1}$ & $\phi_{2}$ & $\phi_{3}$ & $\phi_{4}$ & $\gamma$ & $\delta$ \\
\hline Constitutional & 1.52 & 0.46 & 0.69 & -0.02 & 0.01 & -0.17 & 0.08 & 0.04 & 1.00 \\
Changes & $(3.09)$ & $(4.04)$ & $(7.03)$ & $(6.19)$ & $(2.99)$ & $(5.91)$ & $(2.96)$ & $(0.74)$ & - \\
& & & & & & & & $l=7$ & \\
\hline
\end{tabular}

Note: This table reports parameter estimates for the following model:

$$
y_{t}=c+k h_{t}+\varepsilon_{t}, h_{t}^{\frac{\delta}{2}}=\omega+\alpha h_{t-1}^{\frac{\delta}{2}}\left|\varepsilon_{t-1}\right|^{\delta}+\beta h_{t-1}^{\frac{\delta}{2}}+\phi_{1} x_{i, t}^{(p i)}++\phi_{2} x_{u k, t}+\phi_{3} x_{t o, t}+\phi_{4} x_{p d, t}+\gamma y_{t-l}
$$

where $x_{i, t}^{(p i)}$ indicates constitutional changes,

$x_{u k, t}$ is UK interest rate, $x_{t o, t}$ is trade openness, and $\phi_{4} x_{p d, t}$ is public deficit.

The numbers in parentheses are absolute t statistics.

Last, and also of interest, is that we could not detect any significant indirect effects from domestic financial development (proxies by private deposits) or informal political instability (proxied by the occurrence of guerilla warfare). There is no evidence that such factors affect

bivariate and trivariate analysis show that the effects of the UK interest rate, trade openness and public deficit are not affected by the addition of any of the four measures of formal political instability (see tables A8-A10 and A12 in the additional Appendix). 
growth in Argentina indirectly, through the conditional volatility of growth. Recall, however, that we do find that the direct effects of both domestic financial development and guerrilla warfare are substantial (see Table 1).

In summary, we find strong evidence that both informal political instability (constitutional changes) and trade openness have a negative indirect (via volatility) impact on growth whereas UK interest rate and public deficit affect it positively. No other variables in our set of explanatory variables seem to exhibit equally robust estimates of their indirect effects.

\subsection{Dynamic Aspects}

This section investigates how short- and long-run considerations help refine the baseline results above. Another potential benefit from this exercise is that the required use of lags may help ameliorate lingering concerns about endogeneity. This is because in order to estimate short- and long- run relationships, we use the following error correction (P)ARCH form

$$
\Delta y_{t}=\mu+\theta \Delta x_{i, t-l}+\varphi\left(y_{t-1}-c-\zeta x_{i, t-1}\right)+\varepsilon_{t},
$$

where $\theta$ and $\varsigma$ capture the short and long-run effects respectively, and $\varphi$ is the speed of adjustment to the long-run relationship. ${ }^{16}$ This is accomplished by embedding a long-run growth regression into an ARDL model (see Pesaran, 1997, and Pesaran and Shin, 1998) In other words, the term in parenthesis contains the long-run growth regression, which acts as the forcing equilibrium condition

$$
y_{t}=c+\zeta x_{i t}+u_{t}
$$

where $u_{t}$ is $\mathrm{I}(0)$. The short-run effect is captured by the lag of the first difference of informal political instability or financial efficiency variable or one of the explanatory variables $\left(\Delta x_{i, t-l}\right)$. The condition for the existence of a long-run relationship (dynamic stability) requires that the coefficient on the error-correction term be negative and not lower than -2 (that is, $-2<\varphi<0$ ). PARCH effects are incorporated by specifying the error term $u_{t}$ as follows

$u_{t}=e_{t} h_{t}^{\frac{1}{2}}$

Where

$h_{t}^{\frac{\delta}{2}}=\omega+\alpha h_{t-1}^{\frac{\delta}{2}}\left|e_{t-1}\right|^{\delta}+\beta h_{t-1}^{\frac{\delta}{2}}$.

Table 3 presents the full multivariate results, for informal political instability (guerilla warfare and strikes), domestic and international financial development, and trade openness. Again because of space considerations, the additional Appendix (which is available upon

16 As pointed out by Loayaza and Rancière (2006) the requirements for the validity of this methodology are that: i) there exists a long-run relationship between the variables of interest and, ii) the dynamic specification of the model is sufficiently augmented so that the regressors are strictly exogenous and the resulting residual is serially uncorrelated. 
request) reports results for the intermediate steps, that is, those between the results for one by one variables (which are provided in the online supplementary Appendix, see table A.3) and for all variables together. ${ }^{17}$

The estimated coefficient on the error correction term $\varphi$ lies within the dynamically stable range from -0.68 to -0.36 . Regarding the short and long-run estimates, $\theta$ and $\varsigma$ we focus first on those obtained from the informal political instability variables. All four estimates of the short-run coefficients (see the $\theta_{l}$ column) are highly significant and negative and their absolute values are higher than the corresponding values for the long-run coefficients (see the $\varsigma_{1}$ column). This provides supporting evidence for the notion that the duration of the political instability effect does indeed matter and, for guerilla warfare and general strikes, such effects tend to be considerably stronger in the short- than in the long-run as previously noted by Campos and Nugent (2002) and Murdoch and Sandler (2004). As with the univariate analysis (see the online Appendix) both the short- and long-run effects of the UK interest rate are negative (see the $\theta_{3}$ and $\varsigma_{3}$ columns). This is intuitive as it suggests that lower interest rates abroad, ceteris paribus, has helped Argentina to attract foreign capital (in search of higher returns), which is normally thought of as using more advanced technology and hence more productive, which by its turn has a positive effect on economic growth.

What about the results regarding the financial efficiency dimensions? In the long-run, we find that financial efficiency affects growth positively (see the $\varsigma_{2}$ column). Note that this effect is particularly strong when savings deposits are used as a proxy. This result is very much in line with the large empirical literature reviewed by Levine (2005) and it is interesting we can reproduce it with our rather different methodology. Maybe more interestingly, the short-run coefficients tell a very differently story: we find that the short-run impact of financial efficiency on growth is negative and significant (see the $\theta_{2}$ column). Thus our results square well with recent findings by Loayaza and Rancière (2006), among others, in that the sign of the relationship between economic growth and financial development depends on whether these movements are temporary or permanent (the effect being negative in the former and positive in the latter.) It is also important to mention that in the long-run the impact of trade openness is no longer statistically significant. ${ }^{18}$

In summary, our dynamic estimates show that in the short-run mainly four variables have negative effects on growth, however this set is much reduced considering long-run effects. In the long-run political institutions (informal political instability such as guerilla warfare and general strikes) as well as the UK interest rate affect growth negatively while the impact of financial institutions is shown to be positive in the long-term (and larger than the short-run, negative, effect). It is also worth stressing that the effect of trade openness disappears in the long-term.

17 In the univariate analysis, for almost all cases, both the short- and long-run effects of either informal political instability or financial development are significant (see Table A14 in the additional Appendix). Yet, the results from the bivariate analysis suggest that from the four informal political instability variables only guerilla warfare and strikes affect significantly growth in the long-run (see Table A15). Similarly, M3/GDP has no long-run effect on growth in three out of the four cases. Finally, when we control for informal political instability and financial efficiency the effect of public deficit on growth is no longer statistically significant.

18 The results from the trivariate analysis provide ample support (see in the additional Appendix Table A16). 


\subsection{Structural Breaks}

One final important robustness test regards the role of structural breaks. We use the methodology developed by Bai and Perron (2003) to examine whether there are any structural breaks in growth, its volatility, the various political instability series and the first differences of the four financial development variables.

For example, our Bai-Perron results support that general strikes have one structural break, which is dated for year 1955. This is a result of great interest: 1955 is the year of the military coup in which President Juan Domingo Perón was overthrown by the military thus concluding a defining chapter in Argentine history (for details of the other break dates see the supplementary Appendix which is available online).

In summary, we find our results to be quite robust to the inclusion of the structural break dummies. That is, (i) informal political instability (either guerilla warfare or strikes) has a direct negative effect on growth (see the $\lambda_{1}$ column in Table A.4 in the supplementary Appendix), while formal political instability (constitutional changes) have an indirect (through volatility) negative impact on growth (see the $\emptyset_{1}$ column in Table A.5 in the supplementary Appendix) (ii) trade openness affects growth negatively both directly and indirectly (see Tables A.5 and A.6), (iii) financial development affects growth positively in the long-run but negatively in the short-run (see the $\theta_{2}$ and $\varsigma_{2}$ columns in Table A.6 in the supplementary Appendix), (iv) both the short- and long-run impact of the UK interest rate is negative, while trade openness does not affect growth in the long-run(see the $\theta_{3}, \varsigma_{3}$ and $\varsigma_{4}$ columns in Table A.6). It is also noteworthy that the causal negative effect of strikes reflects the period 1955-2000, which is not surprising given the intricate relationship between the Peron government and organized labor. Finally, the most important difference with the previous results is that the direct (indirect) effect of the UK interest rate (public deficit) disappears when we take into account structural breaks. 
Table 3: The Short- and Long-run Growth Effects of Guerrilla Warfare/Strikes, Private Deposits/ Savings Bank Deposits,

UK Interest Rate and Trade Openness

\begin{tabular}{|c|c|c|c|c|c|c|c|c|c|c|}
\hline & $\theta_{1}$ & $\theta_{2}$ & $\theta_{3}$ & $\theta_{4}$ & $\varphi$ & $\varsigma_{1}$ & $\varsigma_{2}$ & $\varsigma_{3}$ & $\varsigma_{4}$ & $\delta$ \\
\hline \multicolumn{11}{|c|}{ Guerilla Warfare } \\
\hline Private & -0.0084 & -0.1114 & -0.0020 & -0.0237 & -0.6814 & -0.0012 & 0.2348 & -0.0034 & -0.0084 & 0.80 \\
\hline \multirow[t]{2}{*}{ Deposits/GDP } & $(2.24)$ & (1.69) & (4.44) & $(5.22)$ & $(5.69)$ & $(3.65)$ & $(1.51)$ & $(3.05)$ & $(1.40)$ & \\
\hline & $l=2$ & $l=3$ & $l=0$ & $l=0$ & & & & & & \\
\hline Savings Bank & -0.0018 & -0.3117 & -0.0053 & -0.0058 & -0.4593 & -0.0009 & 0.1708 & -0.0039 & -0.0108 & 0.80 \\
\hline \multirow[t]{2}{*}{ Deposits/GDP } & $(3.28)$ & $(4.27)$ & $(25.48)$ & $(3.91)$ & $(4.31)$ & $(2.84)$ & $(2.21)$ & (5.54) & (1.43) & \\
\hline & $l=3$ & $l=3$ & $l=0$ & $l=1$ & & & & & & \\
\hline \multicolumn{11}{|c|}{ Strikes } \\
\hline Private & -0.0023 & -0.0949 & -0.0056 & -0.0112 & -0.4516 & -0.0010 & 0.3205 & -0.0039 & -0.0059 & 0.80 \\
\hline \multirow[t]{2}{*}{ Deposits/GDP } & $(7.70)$ & $(2.48)$ & $(19.57)$ & $(8.41)$ & $(9.60)$ & $(2.23)$ & (1.57) & $(4.95)$ & $(0.67)$ & \\
\hline & $l=3$ & $l=1$ & $l=0$ & $l=3$ & & & & & & \\
\hline Savings Bank & -0.0015 & -0.2052 & -0.0025 & -0.0194 & -0.3582 & -0.0006 & 0.3779 & -0.0038 & -0.0092 & 0.80 \\
\hline \multirow[t]{2}{*}{ Deposits/GDP } & $(3.54)$ & $(2.02)$ & $(5.21)$ & (3.79) & (7.13) & $(1.95)$ & (3.47) & (5.08) & (1.19) & \\
\hline & $l=3$ & $l=1$ & $l=0$ & $l=0$ & & & & & & \\
\hline
\end{tabular}

Note: This table reports parameter (mean) estimates for the following model:

$\Delta y_{t}=\mu+\theta_{1} \Delta x_{i, t-l}^{(p i)}+\theta_{2} \Delta x_{i, t-l}^{(f d)}+\theta_{3} \Delta x_{u k, t-l}+\theta_{4} \Delta x_{t o, t-l}+\varphi\left(y_{t-1}-c-\varsigma_{1} x_{i, t-1}^{(p i)}-\varsigma_{2} x_{i, t-1}^{(f d)}-\varsigma_{3} x_{u k, t-1}-\varsigma_{4} x_{t o, t-1}\right)+\varepsilon_{t}$

$h_{t}^{\frac{\delta}{2}}=\omega+\alpha h_{t-1}^{\frac{\delta}{2}}\left|\varepsilon_{t-1}\right|^{\delta}+\beta h_{t-1}^{\frac{\delta}{2}}$, The four $\theta^{\prime} \mathrm{s}\left(l\right.$ is the order of the lag ) and $\varsigma^{\prime} \mathrm{s}$ capture the short- and long-run effects respectively. $\varphi$ indicates the speed of adjustment to the

long-run relationship. $x_{i, t-l}^{(p i)}$ denotes an informal political instability (either guerilla warfare or strikes) variable .

$x_{i, t-l}^{(f d)}$ denotes a .nancial development (either private deposits/GDP or savings bank deposits/GDP) variable,

$x_{u k, t-l}$ is UK interest rate, $x_{t o, t-l}$ is trade openness. The numbers in parentheses are absolute $t$ statistics. 


\section{Conclusions and Suggestions for Future Research}

What is the relationship between financial institutions, political institutions, trade openness, financial integration, and inflation, on the one hand, and economic growth and volatility, on the other? Are these effects systematically different? Does the intensity and direction (i.e. sign) of these effects vary over time, in general and, in particular, do they vary with respect to short- versus long-run considerations? This paper tries to answer these questions using the PARCH framework and data for Argentina covering the period from the 1890s to the 2000s.

Our main results are as follows. The main explanatory factors, simply in terms of their direct effects on economic growth, turn out to be financial development, informal political instability (guerilla warfare or general strikes) and trade openness. In addition, we find evidence that both formal political instability (constitutional changes) and trade openness affect growth indirectly (and negatively) via growth volatility. There are also important differences in terms of their short- and long-run behavior, more specifically, while the (negative) effects of political instability and of the UK interest rate are similar in the long- and short-run, the effect of financial development is negative in the short- and positive in the long-run. The negative effect of trade openness we find in the short-run disappears in the long-run. Finally, public deficits and inflation are important variables but our results show that their effects are significant either very early (before 1930) or much later (after 1970.)

We here define a "first-order effect" when a variable has a significant (a) direct or (b) indirect impact, and (c) significant short- and long-run effects, and (d) which are robust to structural breaks. We define a "second-order effect" when there is evidence for one or more of these effects but not for all. On this basis, we argue that two factors have first-order effects to understand economic growth over the very long-run in Argentina: financial development and political institutions. There are a few noteworthy second-order effects, for example, international financial integration has negative short- and long-run effects (but no direct nor indirect), whereas trade openness seem to have significant indirect and short-run effects (but no significant long-run effects.)

These findings are of interest in themselves but they also raise a number of new questions that we believe may be useful in motivating future research. We highlight three suggestions. Regarding the role of finance in the process of economic development, our finding supports a large body of previous research in that we also show a strong, positive impact of financial development on growth in the long-run. We find that different forms of political instability affect growth through different channels over different time windows, making up for a strong and resilient effect that proves rather powerful vis-à-vis the benefits brought by financial development. We cannot forget however that Argentina is unique: no other country in the world since the Industrial Revolution went from riches to rags. Argentina is an outlier and further research could try to replicate our analysis using the historical experience of other countries (ideally in a panel setting). Studying the relationship between financial development and economic growth in a panel of developing countries over the very 
long-run would strengthen what we know about the finance and growth nexus. Yet, the data requirements are substantial, with most developing countries lacking historical data even for key series, such as per capita GDP.

A second suggestion for future research is to relax this stark differentiation between first and second order effects by, for example, investigating potential interactions among the various competing explanations discussed above. Future research will surely benefit from investigating more intricate causal chains. This will help further qualify our results in that it will allow to assess the possibility that we find say that a factor "only" has a secondary effect because the method is not capturing the possibility of indirect effects through other variables. Just to give some examples of the type of questions we have in mind: is the effect of trade openness on growth and growth volatility mostly through say informal political instability? Is the role of institutional change in the Argentine debacle magnified by macroeconomic instability? The objective of this paper was to carry out an obviously important "horse race" that has not been tried previously. We hope our results showing the importance of finance and institutions discourage monocausal explanations and motivate future research that focus on complex interactions and more nuanced inter-relationships among the many variables that have been so far identified as competing explanations for the Argentine puzzle.

The third suggestion refers to a possible methodological improvement, namely the application of the bivariate GARCH model to the problem at hand (albeit the relatively small number of observations). The joint estimation of the political instability-financial development-growth system in panel of countries would clearly represent progress and is something we feel future research should try to address. 


\section{References}

Acemoglu, D. (2009). Introduction to Modern Economic Growth. Princeton NJ: Princeton University Press.

Acemoglu, D., Johnson, S., \& Robinson, J. (2005). Institutions as the Fundamental Cause of Long-Run Economic Growth. In P. Aghion \& S. Durlauf (Eds.), Handbook of Economic Growth (pp. 385-472). Amsterdam: Elsevier, North Holland.

Acemoglu, D., \& Robinson, J. (2006). Economic Origins of Dictatorship and Democracy. Boston: Cambridge University Press.

Aghion, P., \& Marinescu, I. (2008). Cyclical budgetary policy and economic growth: What do we learn from OECD panel data? NBER Macroeconomics Annual 2007, Vol. 22 , pp. $251-278$.

Alston, L., \& Gallo, A.A. (2010). Electoral Fraud, the Rise of Peron, and Demise of Checks and Balances in Argentina. Explorations in Economic History, 47, 179-197.

Bai, J. \& Perron, P. (2003). Critical Values for Multiple Structural Change Tests. The Econometrics Journal, 6, 72-78.

Banks, A. (2005). Cross-National Time-Series Data Archive. Jerusalem: Databanks International. http://www.databanks.sitehosting.net.

Bordo, M., Eichengreen, B., Klingebiel, D., \& Martinez-Peria, M.S. (2001). Is the Crisis Problem Growing more Severe? Economic Policy, 16, 51 - 82.

Bussiere, M. \& Fratzscher, M. (2008), Financial openness and growth: short-run gain, long-run pain? Review of International Economics 16(1), 69-95.

Campos, N.F., \& Karanasos, M.G. (2008). Growth, Volatility and Political Instability: Non-Linear Time-Series Evidence for Argentina, 1896-2000. Economics Letters, 100, 135-137.

Campos, N.F., Karanasos, M.G., \& Karoglou, M. (2011). Apocalypse Now, Apocalypse Then, Apocalypse When? Estimating Structural Breaks in Argentinean Economic Growth (1886-2003). Unpublished Manuscript.

Campos, N.F., Karanasos, M.G., \& Tan, B. (2012). Two to Tangle: Financial Development, Political Instability and Economic Growth in Argentina. Journal of Banking and Finance, 36, 290-304. 
Campos, N.F., \& Nugent, J.B. (2002). Who is Afraid of Political Instability? Journal of Development Economics, 67, 157-172.

Cortes Conde, R. (2009). The Political Economy of Argentina in the Twentieth Century. Cambridge: Cambridge University Press.

Diaz-Alejandro, C. (1985). Argentina, Australia and Brazil Before 1929. In D.C.M Platt, \&G. di Tella (Eds.), Argentina, Australia and Canada. Studies in Comparative Development1870-1965 (pp. 95-109). New York: St. Martin's Press.

Ding, Z., Granger, C.W.J., \& Engle, R.F. (1993). A Long Memory Property of Stock Market Returns and a new Model. Journal of Empirical Finance, 1, 83-106.

Dotsey, M. \& Sarte, P. (2000). Inflation uncertainty and growth in a cash-in-advance economy. Journal of Monetary Economics, 45(3): 631-655.

Durlauf, S.N., Johnson, P.A., \& Temple, J.R.W. (2005). Growth Econometrics. In P. Aghion \& S.N. Durlauf (Eds.), Handbook of Economic Growth (pp. 555-677). Amsterdam: North-Holland.

Fountas, S., \& Karanasos, M. (2007). Inflation, Output Growth, and Nominal and Real Uncertainty: Empirical Evidence for the G7. Journal of International Money and Finance, 26, 229-250.

della Paolera, G., \& Taylor, A.M. (1998). Finance and Development in an Emerging Market: Argentina in the Interwar Period. In J.H. Coatsworth \& A.M. Taylor (Eds.), Latin America and the World Economy since 1800 (pp.139-169). Cambridge: Harvard University Press.

della Paolera, G., \& Taylor, A.M. (Eds.) (2003). A New Economic History of Argentina. Cambridge: Cambridge University Press.

di Giovanni, Julian \& Levchenko, A. (2009). Trade openness and volatility. Review of Economics and Statistics 91(3): 558-585.

Grier, K.B., \& Tullock, G. (1989). An Empirical Analysis of Cross-National Economic Growth, 1951-1980. Journal of Monetary Economics, 24, 259-276.

Haber, S.H., North, D.C., \& Weingast, B.R. (Eds.). (2008). Political Institutions and Financial Development. Palo Alto: Stanford University Press.

Karanasos, M., \& Kim, J. (2006). A Re-examination of the Asymmetric Power ARCH Model. Journal of Empirical Finance, 13, 113-128. 
Kehoe, T.J. (2003). What can we Learn from the Current Crisis in Argentina? Scottish Journal of Political Economy, 50, 609-633.

Kehoe, T.J., \& Prescott E.C. (Eds.) (2007). Great Depressions of the Twentieth Century, Federal Reserve Bank of Minneapolis.

Levine, R. (2005). Finance and Growth: Theory and Evidence. In P. Aghion \& S. Durlauf (Eds.), Handbook of Economic Growth (pp. 865-923). Amsterdam: Elsevier.

Lin, J.Y., \& Nugent, J.F. (1995). Institutions and Economic Development. In J. Behrman \& T.N. Srinivasan (Eds.), Handbook of Economic Development, Vol. 3A (pp. 2301-2370). Amsterdam: Elsevier, North Holland.

Loayza, N.V., \& Rancière, R. (2006). Financial Development, Financial Fragility and Growth. Journal of Money Credit and Banking, 38, 1051-1076.

Mitchell, B.R. (2003). International Historical Statistics: The Americas, 1750-2000. London: Palgrave MacMillan.

Murdoch, J.C., \& Sandler, T. (2004). Civil Wars and Economic Growth: Spatial Dispersion. American Journal of Political Science, 48, 138-151.

Panizza, U., \& Presbitero, A. (2013). Public debt and economic growth in advanced economies: A survey. Swiss Journal of Economics and Statistics 149, 175-204.

Pesaran, M.H. (1997). The Role of Economic Theory in Modelling the Long Run. Economic Journal,107, 178-191.

Pesaran, M.H., \& Shin, Y. (1998). An Autoregressive Distributed-Lag Modelling Approach to Cointegration Analysis. In S. Strom (Ed.), Econometrics and Economic Theory in the 20th Century: the Ragnar Frisch Centennial Symposium, Chapter 11 (pp. 371-413). Cambridge: Cambridge University Press.

Prados de la Escosura, L., \& Sanz-Villarroya, I. (2009). Contract Enforcement, Capital Accumulation and Argentina's Long-Run Decline. Cliometrica, 3, 1-26.

Ramey, G., \& Ramey, V. (1995). Cross-Country Evidence on the Link between Volatility and Growth. American Economic Review, 85, 1138-1151.

Rock, D. (1986). Argentina in 1914: The Pampas, the Interior, Buenos Aires. In L. Bethell (Ed.), The Cambridge History of Latin America, Volume V (pp. 393-418). Cambridge: Cambridge University Press. 
Sanz-Villarroya, I. (2005). The Convergence Process of Argentina with Australia and Canada: 1875-2000. Explorations in Economic History, 42, 439-458.

Sanz-Villarroya, I. (2007). La Belle Époque de la Economía Argentina. 1875-1913. Acciones e Investigaciones Sociales, 23, 115-138.

Sen, K. (2013). The Political Dynamics of Economic Growth. World Development, 47, 71-86.

Solberg, C.E. (1987). The Prairies and the Pampas: Agrarian Policy in Canada and Argentina: 1880-1930. Stanford: Stanford University Press.

Spolaore, E., \& Wacziarg, R. (2013). How Deep are the Roots of Economic Development? Journal of Economic Literature, 51, 325-369.

Taylor, A.M. (1992). External Dependence, Demographic Burdens and Argentine Economic Decline after the Belle Epoque. The Journal of Economic History, 52, 907-936.

Taylor, A.M. (2003). Capital Accumulation. In G. della Paolera \& A.M. Taylor (Eds.), A New Economic History of Argentina (pp. 170-196). Cambridge: Cambridge University Press.

Taylor, A.M. (2014). The Argentina Paradox: Microexplanations and macropuzzles. NBER Working paper 19924.

Véganzonès, M-A., \& Winograd, C.D. (1997). Argentina in the 20th Century. An Account of Long-Awaited Growth. Paris: Organization for Economic Co-operation and Development. 


\section{APPENDIX}

\section{A1. Direct Growth Effects}

Table A1 reports the results from the $(\mathrm{P}) \mathrm{ARCH}(1,1)$ model for each one of the explanatory variables. The parameter we are most interested in is $\lambda$ (in the third column.)The results reveal that the direct effect of financial development (private deposits/GDP) on per capita economic growth rates is positive and statistically significant, those of informal political instability (guerrilla warfare),trade openness, and public deficit are negative, ${ }^{19}$ whereas the effects of formal political instability (constitutional changes), international financial development (UK interest rate) and inflation are not statistically significant, at conventional levels. ${ }^{20} 21$

Table A1: Direct Effects on Economic Growth: (P)ARCH estimates, Argentina 1896-2003

\begin{tabular}{lccccc}
\hline \hline \multicolumn{1}{c}{$x_{i t} \downarrow$} & $\mathrm{k}$ & $\lambda$ & $\alpha$ & $\beta$ & $\delta$ \\
\hline Inflation & 1.05 & $-4 \times 10^{-5}$ & 0.48 & 0.69 & 0.80 \\
Trade Openness & $(2.42)$ & $(0.71)$ & $(4.34)$ & $(7.66)$ & - \\
& 0.90 & -0.060 & 0.77 & 0.47 & 0.80 \\
Public Deficit & 0.72 & -0.070 & 0.95 & 0.43 & 0.90 \\
& $(1.94)$ & $(3.13)$ & $(3.05)$ & $(2.00)$ & - \\
UK Interest Rate & 0.94 & -0.001 & 0.82 & 0.44 & 0.90 \\
& $(3.86)$ & $(0.37)$ & $(3.64)$ & $(1.61)$ & - \\
Guerilla Warfare & 1.00 & -0.001 & 0.77 & 0.47 & 0.90 \\
& $(3.69)$ & $(4.35)$ & $(5.43)$ & $(3.13)$ & - \\
Constitutional & 1.80 & -0.003 & 0.56 & 0.48 & 0.80 \\
Changes & $(1.99)$ & $(1.35)$ & $(3.01)$ & $(1.25)$ & - \\
Private Deposits & 0.76 & 0.980 & 0.70 & 0.57 & 0.80 \\
/GDP & $(2.66)$ & $(9.21)$ & $(4.99)$ & $(4.94)$ & - \\
\hline
\end{tabular}

Note: This table reports parameter estimates for the following model:

$$
y_{t}=c+k h_{t}+\lambda x_{i t}+\varepsilon_{t} h_{t}^{\frac{\delta}{2}}=\omega+\alpha h_{t-1}^{\frac{\delta}{2}}\left|e_{t-1}\right|^{\delta}+\beta h_{t-1}^{\frac{\delta}{2}}
$$

The numbers in parentheses are absolute $\mathrm{t}$ statistics

19 This result for trade openness is clearly unexpected. Notice, however, that we show below that its short-run effect is negative but the long-run impact is positive (see Table A3 below). 20 We also estimate bivariate regressions to examine the joint effect of informal political instability and financial development on growth. It appears that anti-government demonstrations, assassinations and M3/GDP have little impact on growth. Therefore, in what follows we only use guerrilla warfare, strikes and financial efficiency. These results are found in Table A1 in an additional Appendix which is available upon request.

21 The bivariate and trivariate analysis show that the direct effect of financial efficiency is not affected by the addition of any of the four explanatory variables to the model, with both indicators showing a positive and significant effect and the same conclusion obtains for the case of guerilla warfare and government strikes (see Tables A2-A7 in the additional Appendix which is available upon request).Interestingly, the direct negative effect of public deficit disappears when accounting either for informal political instability or private deposits. The results again show inflation as having little direct impact on growth (see especially Tables A4 and A5). 


\section{A2. Indirect Effects (Via Growth Volatility)}

Table A2 reports the estimation results for each one of the elements in our data set for what we call the indirect effect, which is the effect on growth via the volatility channel. ${ }^{22}$ The parameter we are most interested in is $\mathfrak{I}$ (in the fifth column.) Our results show that the effects of trade openness and formal political instability (in this case, constitutional change) on the conditional volatility of per capita economic growth rates are negative and statistically significant whereas those of inflation, and public deficit are positive and significant. Interestingly, the volatility of growth is independent of changes in financial development and formal political instability. Last, and also of interest, is that we could not detect any significant indirect effects from domestic financial development (proxied by private deposits) or informal political instability (proxied by the occurrence of guerilla warfare).

Table A2: Indirect effect on Economic Growth. (P)ARCH estimates

\begin{tabular}{lcccccc}
\hline \multicolumn{1}{c}{$x_{i t} \downarrow$} & $k$ & $\alpha$ & $\beta$ & $\phi$ & $\gamma$ & $\delta$ \\
\hline Inflation & 1.66 & 0.60 & 0.54 & $5 \times 10^{-5}$ & 0.24 & 0.80 \\
& $(3.03)$ & $(5.36)$ & $(7.52)$ & $(2.98)$ & $(2.44)$ & - \\
Trade Openness & 1.65 & 0.75 & 0.28 & -0.200 & 0.19 & 0.80 \\
& $(2.72)$ & $(6.41)$ & $(0.16)$ & $(3.48)$ & $(2.69)$ & - \\
Public Deficit & 1.02 & 0.69 & 0.45 & 0.120 & 0.29 & 0.80 \\
& $(2.73)$ & $(5.45)$ & $(5.15)$ & $(2.44)$ & $(4.76)$ & - \\
UK Interest Rate & 1.55 & 0.50 & 0.55 & 0.004 & 0.15 & 1.00 \\
& $(2.26)$ & $(2.98)$ & $(5.35)$ & $(1.57)$ & $(4.67)$ & - \\
Guerilla Warfare & 1.12 & 0.73 & 0.46 & 0.001 & 0.10 & 0.90 \\
& $(2.46)$ & $(4.80)$ & $(4.00)$ & $(0.82)$ & $(2.00)$ & - \\
Constitutional & 1.18 & 0.69 & 0.45 & -0.008 & 0.18 & 1.00 \\
Changes & $(1.94)$ & $(4.40)$ & $(4.15)$ & $(3.40)$ & $(3.75)$ & - \\
Private Deposits & 2.05 & 0.41 & 0.62 & 0.580 & 0.40 & 0.80 \\
/GDP & $(2.23)$ & $(3.04)$ & $(6.75)$ & $(0.53)$ & $(5.69)$ & - \\
\hline
\end{tabular}

Note: This table reports parameter estimates for the following model:

$y_{t}=c+k h_{t}+\lambda x_{i t}+\varepsilon_{t} h_{t}^{\frac{\delta}{2}}=\omega+\alpha h_{t-1}^{\frac{\delta}{2}}\left|e_{t-1}\right|^{\delta}+\beta h_{t-1}^{\frac{\delta}{2}}+\phi x_{i t}+\gamma y_{t-6}$

The numbers in parentheses are absolute t statistics

22 In the expressions for the conditional variances reported in the Tables, various lags of growth (from 1 to 12$)$ were considered with the best model $(1=6)$ chosen on the basis of the minimum value of the AIC. 


\section{A3. Dynamics}

Table A3 presents the results on the estimation of short and long-run parameters linking the four explanatory variables with growth. In all cases, the estimated coefficient on the error correction term $(\varphi)$ lies within the dynamically stable range $(-2,0)$. From investigating whether dynamic considerations affect our conclusions, we find important differences in terms of short and long-run behavior of our explanatory variables, more specifically, while the (negative) effects of informal political instability (guerilla warfare),public deficit and UK interest rate are similar in the longand short-run, that of the financial efficiency(private deposits/GDP) and trade openness are negative in the short- and positive in the long-run (see the $\theta$ and $\varsigma$ columns). Interestingly, the coefficient on inflation is not statistically significant.

Table A3: The short-and long-run effects on Growth

\begin{tabular}{lcccccc}
\hline \multicolumn{1}{c}{$x_{i t} \downarrow$} & $\theta$ & $\boldsymbol{\varphi}$ & $\zeta$ & $\alpha$ & $\beta$ & $\delta$ \\
\hline Inflation & $-5 \times 10^{-5}$ & -0.88 & 0.0001 & 0.91 & 0.42 & 0.90 \\
& $(0.75)$ & $(9.98)$ & $(1.53)$ & $(5.22)$ & $(4.81)$ & - \\
Trade Openness & -0.1000 & -0.58 & 0.2500 & 0.65 & 0.61 & 0.90 \\
& $(1.45)$ & $(4.83)$ & $(2.01)$ & $(5.16)$ & $(7.64)$ & - \\
Public Deficit & $l=3$ & & & & & \\
& -0.1100 & -0.60 & -0.1700 & 1.42 & 0.22 & 0.80 \\
& $(9.08)$ & $(25.94)$ & $(5.88)$ & $(4.08)$ & $(2.16)$ & - \\
UK Interest Rate & -0.0150 & -0.39 & -0.0160 & 1.27 & 0.14 & 0.90 \\
& $(4.77)$ & $(7.47)$ & $(4.21)$ & $(3.81)$ & $(0.95)$ & - \\
Guerilla Warfare & -0.0014 & -0.60 & -0.0007 & 1.10 & 0.36 & 0.90 \\
& $(3.38)$ & $(7.20)$ & $(2.59)$ & $(4.19)$ & $(3.59)$ & - \\
Private Deposits & $l=5$ & & & & & \\
/GDP & -1.3500 & -0.44 & 0.9399 & 0.37 & 0.80 & 0.90 \\
& $(1.81)$ & $(4.64)$ & $(23.72)$ & $(2.63)$ & $(6.69)$ & - \\
& $l=5$ & & & & & \\
\hline
\end{tabular}

Note: This table reports parameter estimates for the following model:

$\Delta y_{t}=\mu+\theta \Delta x_{i, t-1}+\varphi\left(y_{t-1}-c-\zeta x_{i, t-1}\right)+\varepsilon_{t}$

$\boldsymbol{h}_{t}^{\frac{\delta}{2}}=\boldsymbol{\omega}+\alpha \boldsymbol{h}_{t-1}^{\frac{\delta}{2}}\left|\boldsymbol{e}_{t-1}\right|^{\mathcal{\delta}}+\beta \boldsymbol{h}_{t-1}^{\frac{\delta}{2}} \cdot \boldsymbol{\theta}(\boldsymbol{l}$ is the order of the lag $)$

and $\zeta$ capture the short-and long-run effects respectively.

$\varphi$ indicates the speed of adjustment to the long-run relationship.

The numbers in parentheses are absolute t statistics 


\section{A4. Structural Breaks}

One final important robustness test regards the role of structural breaks. We use the methodology developed by Bai and Perron (2003) to examine whether there are any structural breaks in growth, its volatility, the various political instability series and the first differences of the four financial development variables. Bai and Perron(2003) address the problem of testing for multiple structural changes under very general conditions on the data and the errors. In addition to testing for the existence of breaks, these statistics identify the number and location of multiple breaks. ${ }^{23}$

In the case of the economic growth series (and, interestingly, also for growth volatility) the Bai-Perron methodology supports two structural break points. ${ }^{24}$ The first occurs for year 1922 and the second for year 1964. For our political instability variables, we find no structural breaks for the guerilla warfare and constitutional changes series, ${ }^{25}$ and we also find no breaks in the four financial development variables. However, our Bai-Perron results support that general strikes have one structural break, which is dated for year 1955. This is a result of great interest: 1955 is the year of the military coup in which President Juan Domingo Perón was overthrown by the military thus concluding a defining chapter in Argentine history. Further, we also find one structural break in legislative elections (it is dated 1949.) With arguably one exception (anti-government demonstrations in 1972, which were motivated by demands for the return of Perón from exile), all the structural breaks in our political instability series occur during Perón governments. Perón was elected president three times. His first term is from 1946 to 1952 . He is re-elected in1951, his second term starts in 1952 and ends abruptly in 1955. His third term is between 1973 (allowed to return from Spain after 18-year exile) and 1974 (suffers fatal heart attack.) Although marked by severe economic problems, the second term (1951 to 1955) is more often remembered by the political instability (the various terrorist attacks being a sad prelude to the so-called "Dirty War" of 1970s.) ${ }^{26}$ In what follows, we incorporate dummy variables in the equations (1), (2) (3) and (6), in the main body of the paper, thus taking into account breaks in growth, its volatility and in the political instability variables (general strikes and legislative elections). First, we introduce the following notation. $D_{1 t}, D_{2 t}$ are (intercept) dummies defined as $D_{1 t}, D_{2 t}=1$ in the periods

23 Campos et al. (2011) provide an extensive discussion of the issue of structural breaks, using a wide battery of structural break tests (in addition to the standard method in this area, Bai-Perron, which is the one presented in this section) and for twelve Argentinean GDP growth series (various different series exist because they were constructed by different authors basically using different estimates for the year before the introduction of the UN System of National Accounts in the late 1950s.)

24 As a measure of volatility we use the power transformed absolute growth $\left|y_{t}\right|$ d.

25 Our data shows no guerilla warfare before 1948 and after 1977.

$26 \mathrm{We}$ also find no structural breaks for assassinations and cabinet changes. Further, we also find one structural break in cabinet size (dated 1946) while in anti-government demonstrations we find two breaks dated 1954 and 1972 (see graph A3 in the additional Appendix which is available upon request). 
1922-2000 and 1964-2000, respectively, and $D_{1 t}, D_{2 t}=0$ otherwise. Similarly, $D_{i t}$ is a (slope) dummy indicating the period which starts from the year of the break in the political instability variable $\left(\mathrm{x}_{\mathrm{it}}\right)$. For example for strikes $D_{i t}=1$ in the period from 1955 to 2000 whereas for legislative elections $D_{i t}=1$ during the period from 1949 until the end of the sample. The augmented model is given by

$$
y_{t}=c+c_{1} D_{1 t}+c_{2} D_{2 t} k h_{t}+\lambda x_{i t}+\lambda_{d} D_{i t} x_{i t}+\varepsilon_{t}
$$

and

$$
h_{t}^{\frac{\delta}{2}}=\omega+\omega_{1} D_{1 t}+\omega_{2} D_{2 t}+\alpha h_{t-1}^{\frac{\delta}{2}} f\left(e_{t-1}\right)+\beta h_{t-1}^{\frac{\delta}{2}}+\phi x_{i t}+\phi D_{i t} x_{i t}+\gamma y_{t-1}
$$

Recall that the coefficients $\varnothing$ and $\lambda$ capture the impacts of the political instability variable on growth and its volatility respectively. Similarly, $\emptyset_{d}$ and $\lambda_{d}$ correspond to the two effects from the year of the break onwards. Thus the two effects are captured by $\varnothing$ and $\lambda$ in the period up to the year of the structural break, and by $\emptyset+\emptyset_{\mathrm{d}}$ and $\lambda+\lambda_{d}$ during the period from the year of the break until the end of the sample. As above in order to study the direct effects of political instability and financial development we specify model 1 with $\emptyset=\emptyset_{d}=0$; while model 2 with $\lambda=\lambda_{d}=0$ allows us to investigate their indirect impacts on growth.

We also incorporate intercept dummies and level effects in the error correction equation (3) and conditional variance equation (6), as follows

$$
\begin{aligned}
& \Delta y_{t}=\mu+\mu_{1} D_{1 t}+\mu_{2} D_{2 t}+\theta \Delta x_{i, t-1}+\varphi\left(y_{t-1}-c-\zeta x_{i, t-1}\right)+\varepsilon_{t}, \\
& h_{t}^{\frac{\delta}{2}}=\omega+\omega_{1} D_{i t}+\omega_{2} D_{2 t}+\alpha h_{t-1}^{\frac{\delta}{2}}\left|e_{t-1}\right|^{\delta}+\beta h_{t-1}^{\frac{\delta}{2}}+\gamma y_{t-1} .
\end{aligned}
$$

In summary, we find our results to be quite robust to the inclusion of the structural break dummies. That is, (i) informal political instability (either guerilla warfare or strikes) has a direct negative effect on growth (see the $\lambda_{1}$ column in Table A4 in the supplementary Appendix), while formal political instability (constitutional changes) have an indirect (through volatility) negative impact on growth (see the $\mathfrak{I}_{1}$ column in Table A5 in the supplementary Appendix) (ii) trade openness affects growth negatively both directly and indirectly (see Tables A5 and A6), (iii) financial development affects growth positively in the long-run but negatively in the short-run (see the $\theta_{2}$ and $\varsigma_{2}$ columns in Table A.6 in the supplementary Appendix), (iv) both the short- and long-run impact of the UK interest rate is negative, while trade openness does not affect growth in the long-run(see the $\theta_{3}, \varsigma_{3}$ and $\varsigma_{4}$ columns in Table A6). It is also noteworthy that the causal negative effect of strikes reflects the period 1955-2000, which is not surprising given the intricate relationship between the Peron government and organized labor. Finally, the most important difference with the previous results is that the direct (indirect) effect of the UK interest rate (public deficit) disappears when we take into account structural breaks. 
Table A4: Direct Effect of Guerrilla Warfare/Strikes, Private Deposits/Saving Bank Deposits, UK Interest Rate and Trade Openness on Economic Growth. Dummies and $(\mathrm{P}) \mathrm{ARCH}$ estimates

\begin{tabular}{|c|c|c|c|c|c|c|c|c|c|c|c|c|}
\hline & $c_{1}$ & $c_{2}$ & $\mathrm{k}$ & $\lambda_{1}$ & $\lambda_{2}$ & $\lambda_{3}$ & $\lambda_{4}$ & $\omega_{1}$ & $\omega_{2}$ & $\alpha$ & $\beta$ & $\delta$ \\
\hline$x_{i, t}^{(f d)} \downarrow$ & \multicolumn{12}{|c|}{ Guerrilla Warfare } \\
\hline Private & -0.032 & 0.054 & 0.698 & -0.001 & 0.422 & -0.0002 & -0.028 & - & 0.031 & 0.71 & 0.36 & 1.00 \\
\hline Deposits/GDP & $(2.38)$ & $(4.48)$ & $(1.06)$ & $(4.01)$ & $(3.17)$ & $(0.39)$ & $(4.05)$ & & (3.19) & (1.89) & (3.07) & - \\
\hline Saving Bank & - & 0.059 & -1.060 & -0.001 & 0.237 & -0.0010 & -0.026 & - & 0.038 & 0.73 & 0.38 & 0.80 \\
\hline \multirow[t]{2}{*}{ Deposits/GDP } & & $(6.99)$ & $(1.22)$ & $(3.52)$ & $(3.87)$ & $(1.08)$ & $(2.69)$ & & $(2.82)$ & $(5.15)$ & $(2.82)$ & - \\
\hline & & & & & & Strikes & & & & & & \\
\hline Private & - & 0.063 & 1.121 & -0.002 & 0.180 & -0.0010 & -0.055 & - & 0.017 & 0.41 & 0.60 & 1.10 \\
\hline Deposits/GDP & & $(5.69)$ & $(0.80)$ & $(2.67)$ & $(0.44)$ & $(0.36)$ & $(2.50)$ & & $(3.83)$ & $(2.83)$ & (3.83) & - \\
\hline Saving Bank & -0.009 & - & 0.893 & -0.001 & 0.375 & -0.0010 & -0.048 & 0.015 & 0.074 & 0.84 & 0.08 & 1.00 \\
\hline Deposits/GDP & $(15.4)$ & & $(1.00)$ & $(1.76)$ & $(2.52)$ & $(1.17)$ & $(4.28)$ & $(3.50)$ & (1.90) & $(5.46)$ & (1.19) & - \\
\hline
\end{tabular}

Note: This table reports parameter estimates for the following model:

$y_{t}=c+c_{1} D_{1 t}+c_{2} D_{2 t}+k h_{t}+\lambda_{1} x_{i t}^{(p i)}+\lambda_{2} x_{i t}^{(f d)}+\lambda_{3} x_{u k, t}+\lambda_{4} x_{t o, t}+\varepsilon_{t}$,

$h_{t}^{\frac{\delta}{2}}=\omega+\omega_{1} D_{i t}+\omega_{2} D_{2 t}+\alpha h_{t-1}^{\frac{\delta}{2}}\left|e_{t-1}\right|^{\delta}+\beta h_{t-1}^{\frac{\delta}{2}}$.

$x_{i t}^{(p i)}$ denotes an informal political instability (either guerrilla warfare or strikes) variable. $x_{i t}^{(f d)}$ denotes a financial development (either private deposits/GDP or saving bank deposits/GDP) variable. $x_{u k, t}$ is UK interest rate, and $x_{t o, t}$ is trade openness. $D_{1 t}, D_{2 t}$ are(intercept) dummies defined as $D_{1 t}, D_{2 t}=1$ in the periods $1922-2000$ and $1964-2000$ respectively, and $D_{1 t}, D_{2 t}=0$ otherwise. The numbers in parentheses are absolute $\mathrm{t}$ statistics 
Table A5: Indirect Effect of Constitutional Changes/ Legislative Elections, UK Interest Rate, Trade Openness, and Public Deficit on Economic Growth. Dummies and (P) ARCH estimates

\begin{tabular}{|c|c|c|c|c|c|c|c|c|c|c|c|c|c|}
\hline & $c_{1}$ & $c_{2}$ & $\mathrm{k}$ & $\omega_{1}$ & $\omega_{2}$ & $\alpha$ & $\beta$ & $\delta$ & $\phi_{1}$ & $\phi_{2}$ & $\phi_{3}$ & $\phi_{4}$ & $\gamma$ \\
\hline Constitutional & - & - & 5.219 & - & 0.031 & 0.241 & 0.548 & 1.00 & -0.003 & 0.005 & -0.076 & 0.018 & 0.095 \\
\hline \multirow[t]{2}{*}{ Changes } & & & $(3.67)$ & & $(3.37)$ & $(1.90)$ & $(4.30)$ & - & (3.49) & (1.89) & $(3.07)$ & $(1.36)$ & (3.43) \\
\hline & & & & & & & & & & & & & $l=7$ \\
\hline
\end{tabular}

Note: This table reports parameter estimates (interest) for the following model: $y_{t}=c+c_{1} D_{1 t}+c_{2} D_{2 t}+k h_{t}+\varepsilon_{t}$

$h_{t}^{\frac{\delta}{2}}=\omega+\omega_{1} D_{i t}+\omega_{2} D_{2 t}+\alpha h_{t-1}^{\frac{\delta}{2}}\left|e_{t-1}\right|^{\mathcal{S}}+\beta h_{t-1}^{\frac{\delta}{2}}+\phi_{1} x_{i t}^{(p i)}+\phi_{2} x_{u k, t}+\phi_{3} x_{t o, t}+\phi_{4} x_{p d, t}+\gamma y_{t-1}$.

Where $x_{i t}^{(p i)}$ indicates a formal political variable (constitutional changes).

$x_{u k, t}$ is UK interest rate, $x_{t o, t}$ is trade openness and $x_{p d, t}$ is public deficit.

$D_{1 t}, D_{2 t}$ are (intercept) dummies defined as $D_{1 t}, D_{2 t}=1$ in the periods 1922-2000 and 1964-2000 respectively, and $D_{1 t}, D_{2 t}=0$ otherwise.

The numbers in parentheses are absolute $t$ statistics 
Table A6: Short-and long-run Growth effects of Guerrilla Warfare/ Strikes, Private Deposits/Saving Bank Deposits, UK Interest Rate, and Trade Openness

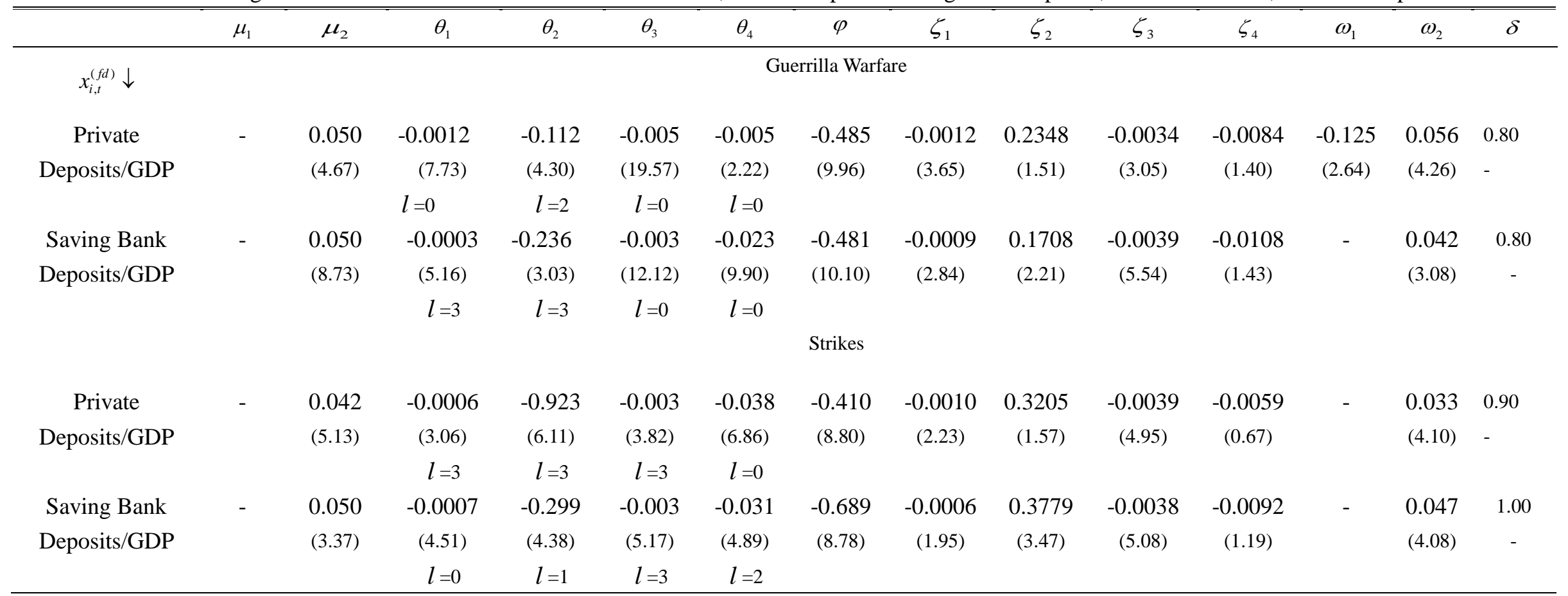

Note: This table reports parameter estimates (of interest) for the following model:

$\Delta y_{t}=\mu+\mu_{1} D_{1 t}+\mu_{2} D_{2 t}+\theta_{1} \Delta x_{i, t-1}^{(p i)}+\theta_{2} \Delta x_{i, t-1}^{(f d)}+\theta_{3} \Delta x_{u k, t-1}+\theta_{4} \Delta x_{t o, t-1}+\varphi\left(y_{t-1}-c-\zeta_{1} x_{i, t-1}^{(p i)}-\zeta_{2} x_{i, t-1}^{(f d)}-\zeta_{3} \Delta x_{u k, t-1}-\zeta_{4} \Delta x_{t o, t-1-}\right)+\mu_{t}$,

$h_{t}^{\frac{\delta}{2}}=\omega+\omega_{1} D_{i t}+\omega_{2} D_{2 t}+\alpha\left|\mu_{t-1}\right|^{\delta}+\beta h_{t-1}^{\frac{\delta}{2}}$. The $\theta s(l$ is the order of the lag) and the four $\zeta$ 's capture the short-and long-run effects respectively. $\varphi$ indicates speed of adjustment to

the relationship. $x_{i, t-1}^{(f d)}$ denotes a financial development variable. $x_{i t-1}^{(p i)}$ denotes an informal political instability variable. $x_{u k, t}$ is UK interest rate, $x_{t o, t}$ is trade openness and $x_{p d, t}$ is public deficit. $D_{1 t}, D_{2 t}$ are (intercept) dummies defined as $D_{1 t}, D_{2 t}=1$ in the periods 1922-2000 and 1964-2000 respectively, and $D_{1 t}, D_{2 t}=0$ otherwise. The numbers in parentheses are absolute $\mathrm{t}$ statistics. 